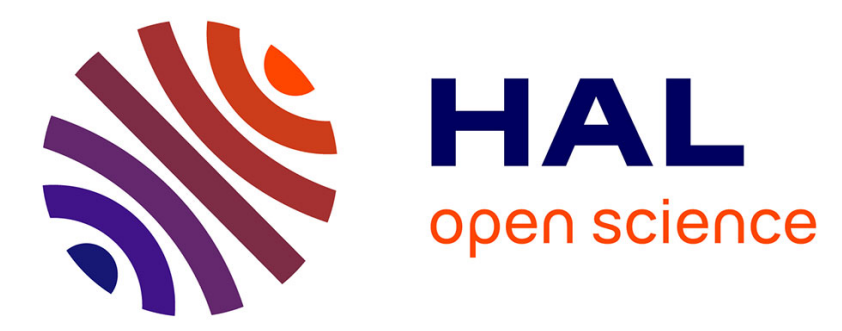

\title{
7-ethylresofurin O-deethylase activity and level of DNA-adducts in trout treated with benzo(a)pyrene
}

J.F. Masfaraud, A. Pfohl-Leszkowic, C. Malaveille, G. Keith, Gilles Monod

\section{To cite this version:}

J.F. Masfaraud, A. Pfohl-Leszkowic, C. Malaveille, G. Keith, Gilles Monod. 7-ethylresofurin Odeethylase activity and level of DNA-adducts in trout treated with benzo(a)pyrene. Marine Environmental Research, 1992, 34, pp.351-354. 10.1016/0141-1136(92)90133-7 . hal-02715968

\section{HAL Id: hal-02715968 \\ https://hal.inrae.fr/hal-02715968}

Submitted on 1 Jun 2020

HAL is a multi-disciplinary open access archive for the deposit and dissemination of scientific research documents, whether they are published or not. The documents may come from teaching and research institutions in France or abroad, or from public or private research centers.
L'archive ouverte pluridisciplinaire HAL, est destinée au dépôt et à la diffusion de documents scientifiques de niveau recherche, publiés ou non, émanant des établissements d'enseignement et de recherche français ou étrangers, des laboratoires publics ou privés. 


\title{
7-Ethylresorufin $O$-Deethylase Activity and Level of DNA-Adducts in Trout Treated with Benzo(a)pyrene
}

\author{
Jean-François Masfaraud, ${ }^{a}$ Annie Pfohl-Leszkowic, ${ }^{b}$ \\ Christian Malaveille, ${ }^{c}$ Gérard Keith $^{b}$ \& Gilles Monod ${ }^{a}$ \\ aLaboratoire d'Ecotoxicologie INRA-ENVL. B.P. 83. 69280 Marcy l'Etoile. France \\ ${ }^{b}$ Laboratoire de Biochimic IBMC-CNRS et Universite Louis Pasteur, 15 rue Descartes, \\ 69084 Strasbourg. France \\ 'International Agency for Research on Cancer, 150 cours Albert Thomas. \\ 69372 Lyon Cedex 08, France
}

\begin{abstract}
In fish, as well as in mammals, it is well known that the cytochrome P450)dependent oxidative metabolism of xenobiotics can generate DNA-reactive species. Moreover. this metabolism is known to he inducible by seceral compounds of environmental significance, such as polychlorobiphenlls. polycyclic aromatic hydrocarbons (PAHS) and dioxins. Consequently, we studied the relationship between the degree of induction of the cytochrome P450/A, expressed as that of 7-ethytresorufin O-deethylase (EROD) activity, and the level of DNA-adducts, using the post-labelling assay, in the liver of rainbow trout exposed to benzo( a)plrene (a representative $P A H$ ). The results showed a significant 2- to 4-fold increase in EROD activity 2. 4 and 8 days after treatment, paralleled by an increase in DNA-adduct levels. This work further e'mphasizes the involvement of cytochrome P450IA in the metaholism of benzo(a)pyrene into genotoxic metabolites in rainbow trout.
\end{abstract}

The cytochrome P450-dependent oxidative metabolism of xenobiotics is a major route in a wide range of species. Nevertheless, such metabolism may also result in the production of highly reactive electrophiles that can bind to DNA, RNA or proteins. The rodent cytochrome P450 isoform 1A1, usually assessed through the in-vitro 7 -ethylresorufin $O$-deethylase (EROD) activity measurement, has been shown specifically to be involved in the activation of chemicals and to be induced by compounds of environmental significance such as polychlorobiphenyls, polycyclic aromatic hydrocarbons (PAHs) or dioxins. ${ }^{1}$ Because of its inducibility, the hepatic EROD activity in fish is

Marine Entiron. Res. 0141-1136/92/\$05.00 O 1992 Elsevier Science Publishers Ltd, England. Printed in Great Britain 


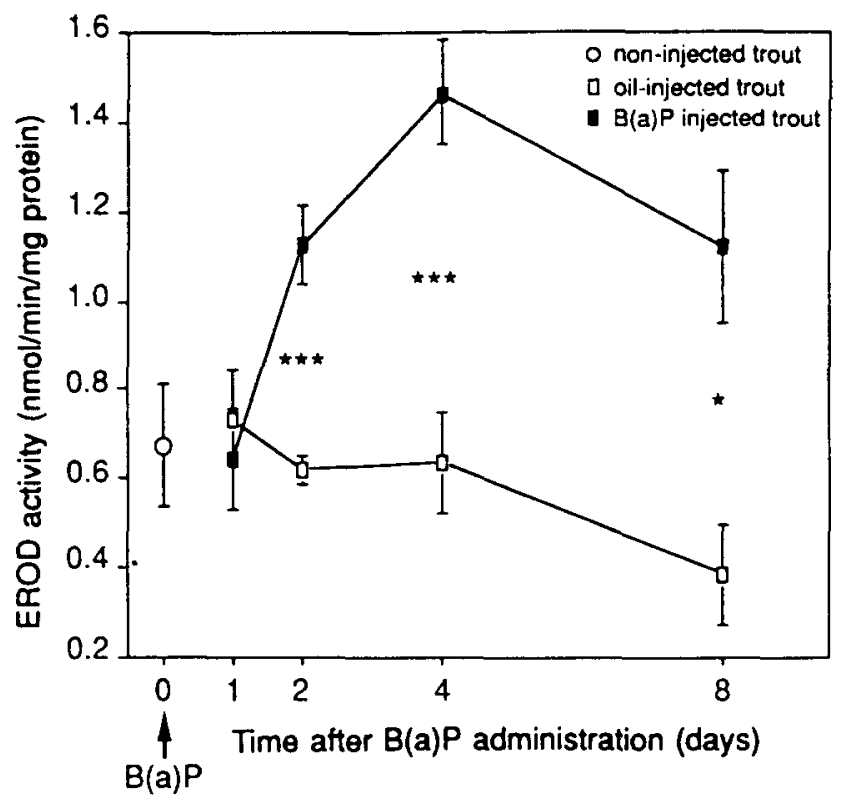

Fig. 1. Time-dependent effect of a single intraperitoneal injection of benzo(a)pyrene on microsomal hepatic EROD activity. Results are mean \pm SEM. with $n=6$ (day $8, n=4$ ). ${ }^{*} p<5 \%,{ }^{* * *} p<0.1 \%$ (Student's $t$-test).

currently used in field studies as a biochemical indicator, providing evidence of exposure to pollutants. ${ }^{2}$ Considering the involvement of the rodent cytochrome $\mathrm{P} 4501 \mathrm{Al}$ in the activation of planar pro-carcinogens into reactive metabolites, we wondered whether EROD activity is associated with their genotoxicity in fish. Therefore. we exposed rainbow trout (Oncorhinchus mykiss) to the model-PAH benzo(a)pyrene (B(a)P) known to induce hepatic microsomal EROD and to be metabolized into DNAdamaging species in mammals ${ }^{3}$ and fish. ${ }^{4}$

Fifty trouts were maintained in tanks with circulating charcoal-filtered tap water at $9 \mathrm{C}$ and fed with commercial pellets. The three experimental groups were as follows: 22 trouts injected intraperitoneally with $\mathrm{B}(\mathrm{a}) \mathrm{P}$ in corn oil $(80 \mathrm{mg} / \mathrm{kg}$ body weight), 22 trouts injected with corn oil alone and six trouts as non-injected controls. $\mathrm{B}(\mathrm{a}) \mathrm{P}$ and corn oil-treated fish were subsequently sacrificed $1(n=6), 2(n=6), 4(n=6)$ and $8(n=4)$ days after treatment. Fish from the non-injected group $(n=6)$ were sampled on the day of treatment. Livers were removed and divided into two parts for microsomal EROD activity and DNA-adduct level determinations. Microsomes were prepared and the EROD activity measured as given in Ref. 5. Liver DNA was isolated following the procedure of Dunn et al. ${ }^{6}$ and DNA-adducts were analysed using the ${ }^{32} \mathrm{P}$-post-labelling assay ${ }^{7}$ after nuclease $\mathrm{P}_{1}$-enrichment. 


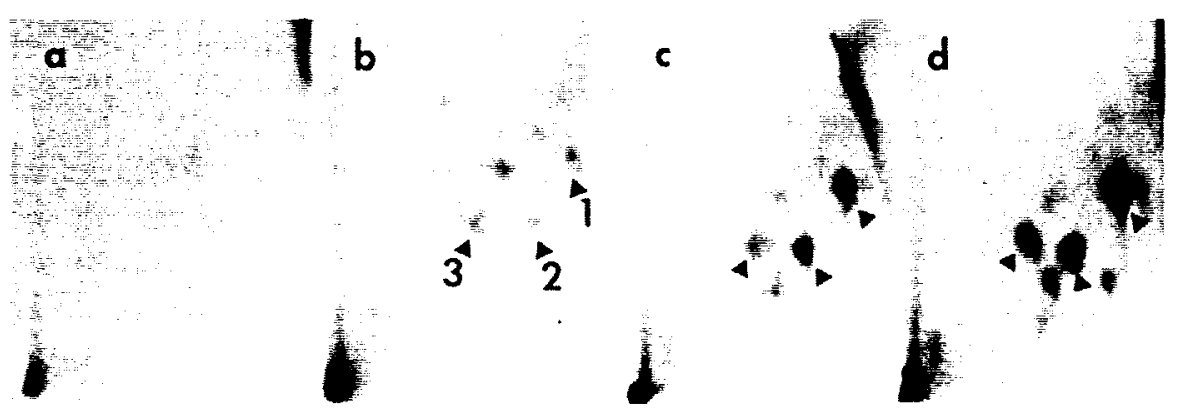

Fig. 2. Representative fingerprints of liver DNA 32 - P-labelled adducts of control (a) and B(a)P-treated trout sampled 1 (b), 2 (c), 4 (d) days after injection (six. six, four and five fish were analyzed, respectively). Ten micrograms of DNA were analysed and the mapping of ${ }^{32} \mathrm{P}-$ labelled adducts was carried out as in Lu et al., ${ }^{1+}$ except that the solvent systems used for these samples were as follows: $2.3 \mathrm{M}$ sodium phosphate, $\mathrm{pH} 5.7$ (D1): $5.3 \mathrm{M}$ lithium formate: $8.5 \mathrm{M}$

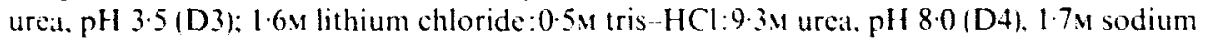
phosphate, $\mathrm{pH} 60$ (D5). Autoradiography was at $-80 \mathrm{C}$ for $17 \mathrm{~h}$ using one intensifying screen. Levels of DNA-adducts are indicated in the cext and expressed as fmol/mg DNA (mean \pm SEM): statistical analysis was carried out using the Dunnett's test. Samples from day 8 were not taken into account because of a technical failure.

Corn oil treatment was without effect on fish liver microsomal EROD activity, while this activity increased from day 1 to day 4 after $B(a) P$ treatment and remained elevated up to day 8 (Fig. 1). The difference between vehicle- and $\mathrm{B}(\mathrm{a}) \mathrm{P}$-treated fish was not significant one day after treatment, but a 2-3-fold enhancement of EROD activity in B(a)P-exposed fish was obtained from 2 to 8 days after treatment (Fig. 1).

Several adducts were detected in the liver DNA from trout, appearing as several spots on the chromatograms of the ${ }^{32}$ P-labelled nucleotides (Fig. 2). Some adducts which were present in the $\mathrm{B}(\mathrm{a}) \mathrm{P}$-exposed fish and whose level remained similar throughout the experiment were also detected in the control group. The nature of such adducts is not clearly known but studies with rodents led to hypothesize that they may be of endogenous origin. ${ }^{8}$ In the $\mathrm{B}(\mathrm{a}) \mathrm{P}$-exposed group, three main adducts were also observed that were slightly detectable in the control group $(2.01 \pm 0.48$ and $1.52 \pm 0.37 \mathrm{fmol} / \mathrm{mg}$ DNA for adducts 1 and 3, respectively; adduct 2 was not detectable; from $n=6$ fish) and that increased significantly (as determined statistically) along the exposure and reached maximum values after two days for adduct 2 $(8.89 \pm 2.99 \mathrm{fmol} / \mathrm{mg}$ DNA, $n=4)$ or four days for adducts 1 and 3 $(16.23 \pm 6.21$ and $7.35 \pm 2.47 \mathrm{fmol} / \mathrm{mg}$ DNA, respectively, $n=5)$. The unidentified adduct 1 was the most intense and represented about $50 \%$ of the total adduct radioactivity 1-4 days after treatment. The adduct 3 was chromatographically identical (data not shown) to the major one detected in mouse skin DNA after topical application of $\mathrm{B}(\mathrm{a}) \mathrm{P}$, which corresponds to 
the 7,8-diol 9,10-epoxide $\mathrm{B}(\mathrm{a}) \mathrm{P}$-guanine adduct, ${ }^{9}$ which is partly responsible for its carcinogenic effect and which has been shown to be the major liver DNA-adduct detected in several fish species exposed to B(a)P. ${ }^{10-12}$

The present study thus confirms that the measurement of EROD activity permits the monitoring of exposure of fish to environmental chemicals such as PAHs. The level of EROD induction has been proposed recently as a means of categorizing xenobiotics on a scale based on dioxin toxicity. ${ }^{13}$ The observation that the formation of liver DNA-adducts was associated with the induction of microsomal EROD activity is consistent with the involvement of cytochrome P4501A in the metabolism of $\mathrm{B}(\mathrm{a}) \mathrm{P}$ into genotoxic metabolites and suggests the genotoxic significance of this enzymatic activity in rainbow trout exposed to B(a)P. Accordingly, EROD induction by non-genotoxic compounds could be a useful indicator of genotoxicity that results from the possible subsequent/concomitant exposure to pro-carcinogens of fish responsive to their biological effect.

\section{ACKNOWLEDGEMENTS}

M. Castegnaro (IARC) is acknowledged for having provided mouse skin DNA and for fruitful discussion, and G. Dirheimer (IBMC-Université Louis Pasteur) for valuable discussion and constant support.

\section{REFERENCES}

1. Okey, A. B. Pharmat. Ther., 45, 241-98 (1990).

2. Payne, J. F., Fancey, L. L., Rahimtula, A. D. \& Porter. E. L. Comp. Biochem. Physiol., 88C, 233-45 (1987).

3. Conney, A. H. Cancer Res., 42, $4875-4917$ (1982).

4. Tan. B. \& Melius, P. Comp. Biochem. Physiol., 83C, $217-24$ (1986).

5. Masfaraud. J. F., Monod, G. \& Devaux, A. Sci. Total Environ., 97/98, 729-38 (1990).

6. Dunn, B. P., Black, J. J. \& Maccubbin, A. Cancer Res., 47, $6543-8$ (1987).

7. Rinderath, K., Reddy, M. V. \& Gupta, R. C. Proc. Natl Acad. Sci. USA, 78, $6126-9(1981)$.

8. Randerath. K.. Reddy, M. V.\& Disher, R. M. Carcinogenesis, 7, 1615-17(1986).

9. Gupta, R. C., Reddy, M. V. \& Randerath, K. Carcinogenesis, 3. 1081-92 (1982).

10. Varanasi, U., Reichert. W. L., Le Eberhart, B. T. \& Stein, J. E. Chem.-Biol. Interactions, 69, 203-16 (1989).

11. Sikka, H. C., Rutkowski, J. P., Kandaswami. C., Kumar, S., Earley, K. \& Gupta, R. C. Cancer Lett., 49,81-7 (1990).

12. Kurelec, B., Krca, S., Garg, A. \& Gupta. R. C. Cancer Lett., 57, 255-60(1991).

13. Safe, S. Chemosphere, 16, 791-802 (1987).

14. Lu. L. J. W., Disher, R. M., Reddy, M. V. \& Randerath, K. Cancer Res., 46. 3046-54 (1986). 